\title{
BIOANALYSIS OF \\ DRUGS AND METABOLITES, \\ Especially Anti-Inflammatory \\ and Cardiovascular
}




\title{
METHODOLOGICAL SURVEYS IN BIOCHEMISTRY AND ANALYSIS
}

\author{
Series Editor: Eric Reid \\ Guildford Academic Associates \\ 72 The Chase \\ Guildford GU2 5UL, United Kingdom
}

The series is divided into Subseries A: Analysis, and B: Biochemistry Enquiries concerning Volumes 1-11 should be sent to the above address.

Volumes 1-10 edited by Eric Reid

Volume 1 (B): Separations with Zonal Rotors

Volume 2 (B): Preparative Techniques

Volume 3 (B): Advances with Zonal Rotors

Volume 4 (B): Subcellular Studies

Volume 5 (A): Assay of Drugs and Other Trace Compounds in Biological Fluids

Volume 6 (B): Membranous Elements and Movement of Molecules

Volume 7 (A): Blood Drugs and Other Analytical Challenges

Volume 8 (B): Cell Populations

Volume 9 (B): Plant Organelles

Volume 10 (A): Trace-Organic Sample Handling

Volume 11 (B): Cancer-Cell Organelles Edited by Eric Reid, G. M. W. Cook, and D. J. Morré

Volume 12 (A): Drug Metabolite Isolation and Determination Edited by Eric Reid and J. P. Leppard (includes a cumulative compound-type index)

Volume 13 (B): Investigation of Membrane-Located Receptors Edited by Eric Reid, G. M. W. Cook, and D. J. Morré

Volume 14 (A): Drug Determination in Therapeutic and Forensic Contexts Edited by Eric Reid and Ian D. Wilson

Volume 15 (B): Investigation and Exploitation of Antibody Combining Sites Edited by Eric Reid, G. M. W. Cook, and D. J. Morré

Volume 16 (A): Bioactive Analytes, Including CNS Drugs, Peptides, and Enantiomers Edited by Eric Reid, Bryan Scales, and Ian D. Wilson

Volume 17 (B): Cells, Membranes, and Disease, Including Renal Edited by Eric Reid, G. M. W. Cook, and J. P. Luzio

Volume 18 (A): Bioanalysis of Drugs and Metabolites, Especially Anti-Inflammatory and Cardiovascular Edited by Eric Reid, J. D. Robinson, and lan D. Wilson

A Continuation Order Plan is available for this series. A continuation order will bring delivery of each new volume immediately upon publication. Volumes are billed only upon actual shipment. For further information please contact the publisher. 


\section{BIOANALYSIS OF DRUGS AND METABOLITES, Especially Anti-Inflammatory and Cardiovascular}

Edited by

Eric Reid

Guildford Academic Associates

Guildford, United Kingdom

J. D. Robinson

Hoechst UK

Milton Keynes, United Kingdom

and

Ian D. Wilson

ICI Pharmaceuticals Division

Macclesfield, United Kingdom

\section{Springer Science+Business Media, LLC}




\section{Library of Congress Cataloging in Publication Data}

International Bioanalytical Forum (7th: 1987: Guildford, Surrey)

Bioanalysis of drugs and metabolites, especially anti-inflammaory and cardiovascular.

(Methodological surveys in biochemistry and analysis; v. 18 (A))

"Proceedings of the Seventh International Bioanalytical Forum . . . held September $8-11,1987$, in Guildford, United Kingdom" - T.p. verso.

Includes bibliographies and indexes.

1. Anti-inflammatory agents-Analysis-Congresses. 2. Cardiovascular agentsAnalysis-Congresses. 3. Arachidic acid-Derivatives-Analysis-Congresses. 4. High performance liquid chromatography -Congresses. 5. Blood - Analysis - Congresses. 6. Chemistry, Clinical-Technique-Congresses. I. Reid, Eric, date. II. Robinson, J. D. III. Wilson, Ian D. IV. Title. V. Series: Methodological surveys in biochemistry and analysis; v. 18. [DNLM: 1. Anti-Inflammatory Agents-analysis-congresses. 2. Cardiovascular Agents-analysis-congresses. 3. Chromatography, Gas-methods-congresses. 4. Chromatography, High Pressure Liquid-methods-congresses. 5. Drugs-analysis congresses. 6. Eicosanoic Acids - metabolism - congresses. W1 ME9612NT v.18 / QV $25 \mathrm{I} 61$ 1987b]

Based on proceedings of the Seventh International Bioanalytical Forum entitled Bioanalysis of Drugs and Metabolites, Especially Anti-Inflammatory and Cardiovascular, held September 8-11, 1987, in Guildford, United Kingdom

\section{(C) Springer Science+Business Media New York 1988 Originally published by Plenum Press, New York in 1988 Softcover reprint of the hardcover 1st edition 1988}

\section{All rights reserved}

No part of this book may be reproduced, stored in a retrieval system, or transmitted in any form or by any means, electronic, mechanical, photocopying, microfilming, recording, or otherwise, without written permission from the Publisher 


\section{Senior Editor's Preface}

Whereas the 'bioactive analytes' coverage of Vol. 16 included endogenous peptides, the present book features eicosanoids, besides drugs. Awareness of the therapeutic potential of such agents was evidenced by the keen participation of company staff in the Bioanalytical Forum (September 1987) which gave rise to this book.

The Forum series, whilst still focused on blood-level determinations, has shown trends which mostly match changes in the analytical scene. Reflecting the tendency of newer drugs to be even more potent than the CNS-active drugs that featured in Vol. 16, analytical concern is increasingly with $\mathrm{ng} / \mathrm{ml}$ or even $\mathrm{pg} / \mathrm{ml}$ levels. Yet reliable measurement is still needed at the $\mu \mathrm{g} / \mathrm{ml}$ level too, notably in re-investigating old-established drugs for pharmacokinetic properties indicated in the text. Both Vol. 16 and the present book manifest the increasing attention to drug chirality.

Metabolite investigation is increasingly aided by NMR (see 'Notes' in Sect. 非). For bioanalysis in general, chromatographic separations have played a cardinal role since the 1970's. Capillary GC has at last burgeoned in the drug-assay area, somewhat reducing the dominance gained by HPLC (for which fluorescence detection is gaining ground). Analysts increasingly seek instrumentation that may be of daunting cost even if the aim is subtlety rather automation. For sample preparation, solvent extraction still serves skilled practitioners as a powerful tool, although largely superseded by 'cartridge' extraction notwithstanding evident pitfalls. In respect of publishing assay methodology, our policy that method-descriptions must include the 'rationale' no longer needs strong advocacy; moreover, it is no longer rare for analysts in pharmaceutical companies to publish their methods. Now an analyst faced with setting up a method may be daunted by the swollen literature. For the analyte in question, the customary Analyte Index in this book (or earlier volumes) riay list the actual compound, or chemically kindred compounds with analytical pertinence. The Table on p. 218 augments the coverage for two therapeutic classes that feature in this book, viz. cardiovascular and anti-inflammatory drugs. (Eicosanoids may likewise be antiinflanmatory, although some may be pro-inflammatory.)

There has been a trend, noted with relief by the Editors, towards better compilation of publication texts. Yet some texts have undergone extensive editing, acceptable to the authors. Erratic alternation of the terms 'serum' and 'plasma', and of the synonymous terms 'precision' and 'reproducibility', caused some trouble in the editing, 
as did non-appreciation that \% values for bought-in solutions (notably ammonia) may be on a weight basis, not made evident by the manufacturer. Notwithstanding the shortcomings or lateness of some texts, authors are thanked for compiling them amidst other pressures. Elsevier and the American Chemical Society are also thanked, for Figures now reproduced with source acknowledgement.

This Editor has generally respected authors' phrasing, whilst shuddering when the term 'incubate' is encountered in a $0^{\circ}$ context. He remains a 'diehard' in certain respects, notably in favouring ' $M$ ' rather than 'mol/l', and a wt./m1 basis for drug concentrations in test samples; he regards 'mmol/1' as a fatuous fashion. Concerning infelicitous abbreviations, a distinction is made between electroncapture (detector context; 'ECD') and electrochemical ('EC', never 'ECD'); the hallowed GC term 'FID' means free induction decay to NMR practitioners, who may pardon the term 'Fid' as introduced editorially. The convention for ${ }^{\circ}{ }^{\circ} \mathrm{C}^{\prime}$ throughout the book is ' 0 '.

Undefined but well-known abbreviations include GC, HPLC and TLC. MS (mass spectrometry), NPD (nitrogen-phosphorus detector), $t_{r}$ (retention time) and RIA (radioimmunoassay) are usually defined in the article concerned, as are the HPLC modes NP (normal-/straightphase) and RP (reversed-phase; C-18 and ODS are synonymous), and i.s. denoting internal standard, about which E. Reid made a plea in Vol. 7 (1978; 非A-6).- "To ascertain what a particular author means by the term 'internal standard', one of ten has to scrutinize the small print in the paper. When taken through the full procedure, it allows for any idiosyncrasy (wobble) in the particular sample." Happily the latter usage now prevails.

Support for the Forum, much appreciated, came from U.K. pharmaceutical companies: Beechams, Glaxo, ICI and Smith Kline \& French. 


\section{Contents}

The 'NOTES \& COMMENTS' ('NC' items) at the end of each Section include cornments (listed on each 'NC' title page) made at the Forum on which the book is based, along with some supplementary material.

Senior Editor's Preface, with an abbreviations list v

List of Authors xii

\# A EICOSANOIDS AND RELATED ANALYTES (pathways: $p .63$ ) ....... 1

\# A-1 The use of HPLC in studies of the stereoselective metabolism of prostaglandin $\mathrm{D}_{2}$ - CLIVE ROBINSON ......... 3

\#A-2 Analysis of eicosanoids by GC-MS/MS - J.C. FRÖLICH, K-H. MARX, H. BIPPI, J. FAULER, B. ROSENKRANZ \& U. FÖRSTERMANIN

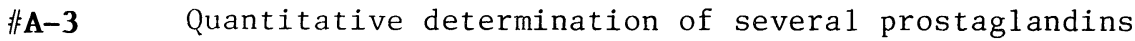
and thromboxane $B_{2}$ in the isolated perfused rat brain CLAUDIA WEBER, KLAUS BELSNER, BARBARA OSIKOWSKA-EVERS, INGE LUHMANN \& MICHAEL HÖLLER

非 A-4 Analytical methods for $\left[{ }^{3} \mathrm{H}\right]$-enisoprost, an antisecretory $\mathrm{PGE}_{1}$ analogue, and its metabolites L.A. ALLAN, A.J. HAWKINS, J. FIRTH, R.D. BROWNSILL, J.A. STEINER \& C.W. VOSE

\#A-5 Identification of a new metabolite of leukotriene $B_{4}$ by RP-HPLC and GC-MS analysis - JOACHIM FAULER, KARL-HEINZ MARX \& VOLKHARD KAEVER

\# A-6 Radioimmunoassay of eicosanoids: its application in the development of anti-inflammatory and analgesic drugS - FRANK CAREY, DUNCAN HAWORTH \& ROBERT A. FORDER .... 43

\#NC $(A) \quad$ NOTES and COMMENTS relating to the foregoing topics .... 51 including Notes on:

\#NC (A)-1 Developing methods for a thromboxane synthetase inhibitor and a prostacyclin analogue in biological fluids: problems and some solutions - M.V. DOIG \& R.A. CLARE

\#NC(A)-2 The stereochemical analysis of monohydroxyfatty acids, particularly 12-hydroxy-5, 8,10,14-eicosatetraenoic acid - P.M. WOOLLARD 
\#B-1 Analysis of the actions of anti-inflamatory drugs, with particular reference to effects on interleukins and leucocytes - K.D. RAINSFORD

非B-2 Immunoassay of beclomethasone 17,21-dipropionate and metabolites - W.N. JENNER \& D.J. KIRKHAM

\#B-3 HPLC analysis of anti-inflammatory agents (nonsteroidal and steroidal) - J.C. McELiNAY

非-4 Analytical approaches adopted during the development of Elurbiprofen - A. BYE, W. ADAMS \& D. KAISER

非-5 The assay of diclofenac and metabolites: a review P.H. DEGEN ....

\#B-6 Enantiomeric analysis of 2-phenylpropionic acid NSAID's in biological fluids by HPLC - A.J. HUTT \& J. CALDWELL .. 115

\#NC(B) NOTES AND COMMENTS relating to the foregoing topics 127 including a Note on:

非NC(B)-1 The determination of suprofen in biological fluids C.J. DYDE, M.F. BARKWORTH \& K.D. REHM

非C ACE INHIBITORS AND CALCIUM ANTAGONISTS

非C-1 Analysis of angiotensin-converting enzymie inhibitors in biological fluids - A. RAKHIT

\#C-2 The analysis of ACE inhibitors by immunoassay J.D. ROBINSON \& S. LEWIS

非-3 The use of stable-isotope methodology in pharmacokinetic studies involving flunarizine - ROBERT WOESTENBORGHS, PHILIP TIMMERMAN, ACHIEL VAN PEER \& JOS HEYKANTS

非CC(C) NOTES and COMMENTS relating to the foregoing topics 157 including Notes on:

非CC(C)-1 Assay problems with nifedipine - P.S.B. MINTY

\& F.A. TUCKER

非C(C)-2 Detection of the metabolites of sone dihydropyridinetype calcium antagonists in urine and plasina $\mathrm{K}-\mathrm{D}$. RÄMSCH \& D. SCHERLING

非D

VARIOUS CARDIOVASCULAR DRUGS

\#D-1 The study of chiral cardiovascular drugs: analytical approaches and some pharmacological consequences RICHARD L. LALONDE, MICHAEL B. BOTTORFF \& IRVTING W. WATNER

非-2 Development of a chiral capillary GC method for the quantitation of the enantiomers of cromakalim in biological fluids - B.E. DAVIES 
\#D-3 The determination of amiodarone and desethylamiodarone by HPLC - B.J. STARKEY, A.J.E. GREEN \& G.P. MOULD .......... 185

非D-4 The assay of hydralazine: a review - P.H. DEGEN ........... 193

\#D-5 Approaches to the analysis of two cardiovascular drugs in plasma - R.D. McDOWALL, J.C. PEARCE, G.S. MURKITT, J.A. JELLY, W.J. LEAVENS, K.A. FERNANDES \& R.M. LEE .... 201

\#NC(D) NOTES and COMMENTS relating to the foregoing topics .... 207 including Hotes on:

\#NC(D)-1 Quantitative analysis of flesinoxan in plasma and urine at the $\mathrm{pg} / \mathrm{ml}$ level using GC-ECD -

M.P. VAN BERKEL, H. DE BREE \& K. SIERAT

非C(D)-2 Assay of nitroglycerin and metabolites by

capillary GC - STEPHEN H. CURRY \& HAE-RYUN KWON

\#NC(D)-3 HPLC-fluorescence method for the determination of the new $\beta_{1}$-adrenoreceptor blocking agent nebivolol in human plasma - ROBERT WOESTENBORGHS, LUC EMBRECHTS \&

JOS HEYKANTS

Table of additional assay procedures (非 \& 沙 C besides 非D) 218

iF $\mathbf{E}$ VARIOUS DRUGS AND SEPARATORY APPROACHES

非-1 The routine use, and column-stability implications, of several column-switching HPLC methods for determining drugs in plasma and urine - J.B. LECAILLON, C. SOUPPART,

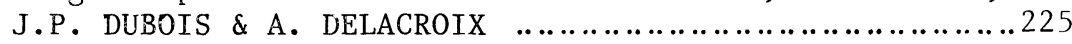

作E-2 Miceilar liquia chromatography - JOHN G. DORSEY ..........235

\#E-3 Determination of nefopam and its desmethyl metabolite in biological fluids by paired-ion RP-HPLC -

A.J. WOODWARD, P.A. LEWIS, J. MADDOCK \& D. DONNELL

ikE-4 An assay for idaverine in plasma and urine at picogram level - D.J.K. VAN DER STEL, O.A.M. BROCKHOFF \& H. DE BREE

洪E-5 Pitfalls in the enantioselective analysis of chiral drugs - JOHN CALDWELL, JOHN F. DARBYSHIRE, STEPHEN M. WINTER \& ANDREW J. HUTT ….......................2 257

\#NAC(E) NOTES and COMMENTS relating to the foregoing topics 263 including Notes on:

\#NC(E)-1 Chiral differences in the disposition of the quaternary anticholinergic drug oxyphenonium bromide KARLA G. FEITSMA, BEN F.H. DRENTH, ROKUS A. DE ZEEUW \& DIRK K.F. MEIJER

非NC(E)-2 Quantitation of danazol in serum using HPLC column switching with UV detection - H.M. HILL \& K. SELINGER .. 269 
非 $\mathbf{N C}(\mathbf{E})-\mathbf{3}$ Simultaneous determination of etretinate, acitretin and 13-cis-acitretin in plasma by gradient-HiPLC using automated column switching - R. WYSS \& F. BUCHELI ......... 271

非NC(E) -4 Analytical consequences of potent drugs - H. DE BREE .... 273

\#NC(E)-5 Optimization of capillary GC conditions for the analysis of psychotropic drugs at subnanogram concentrations in plasma - H.M. HILL, D. LESSARD \& L. LETARTE

\#NC(E)-6 Comparison of an enzyme method with a capillary GC method for red blood cell sorbitol assay -

R.P.B. PASSAS \& D. STEVENSON

\#NC(E)-7 The stability of antineoplastic vinca alkaloids in plasma and urine - D.E.M.M. VENDRIG, A. MEKKING, J. TEEUWSEN \& J.J.M. HOLTHUIS

\#NC(E)-8 Solid-phase extraction: personal experiences ROBIN WHELPTON \& PETER R. HURST

\#NC(E)-9 The use of secondary ionic interactions for the solidphase extraction of some ' $\beta$-blocking' drugs on $\mathrm{C}-1$ ' bonded silica - R.J. RUANE, I.D. WILSON \& G. P. TOMKINSON

\#NC(E)-10 Application of solid-phase extraction techniques to the analysis of basic and acidic drugs in biological fluids - H.M. HILL, L. DEHELEAN \& B.A. BAILEY

非C(E)-11 The determination of drug protein binding by HPLC using a chemically bonded bovine-albumin stationary phase - N. LAMMERS, H. DE BREE, C.P. GROEN, H.M. RUIJTEN \& B.J. DE JONG 301

非CC(E)-12 Retention mechanisms in reversed-phase HPLC JOHN G. DORSEY 305

非 $\mathbf{F}$ DETECTION, IDENTIFICATION AND INSTRUMENTATION 311

非F-1 Advances in instrumentalized TLC - I.D. WILSON

\#F-2 The use of fluorescence and chemiluminescence techniques for sensitive and selective detection in HPLC - U.A.TH. BRINKMAN, G.J. DE JONG \& C. GOOIJER ..... 321

非F-3 LC-MS and LC-MS-MS for biomedical analyses - A.P. BRUINS 339

\#F-4 The structure elucidation of drug metabolites using thermospray LC-MS and LC-MS-MS - T.J.A. BLAKE $\&$ I.G. BEATTIE

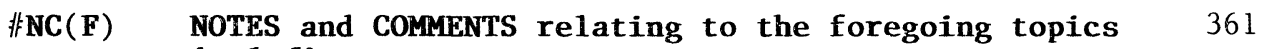
including Notes on:

非C(F)-1 An approach to metabolite sample preparation for mass spectrometry to aid the spectroscopist - R.D. BROWNSILL, A. GRAY \& C.W. VOSE 
\#NC(F)-2 Application of NMR and mass spectrometry to the study of drug hydroxylation - C.M. WALLS, A. GRAY, R.D. BROWNSILL 367 \& C.W. VOSE

非C (F)-3 Urinanalysis by ${ }^{1} \mathrm{H}$ NMR: application to cephaloridinetreated rats - R. PICKFORD, I.K. SIMITH \& I.D. WILSON

\#政C(F)-4 Proton NMR studies on the metabolism and biochemical effects of hydrazine in vivo - S.M. SANINS, J.A. TIMBRELL, C. ELCOMBE \& J.K. NICHOLSON

非CC(F)-5 ${ }^{19} \mathrm{~F}$ NMR studies of the metabolism of trifluoromethy1aniline - K.E. WADE, J. TROKE, C.M. MACDONALD, I.D. WILSON \& J.K. NICHOLSON

\#NC(F)-6 NMR as an aid in studying $N$-alkylformamides and metabolites - MICHAEL D. THREADGILL \& ANDREAS GESCHER

非C(F)-7 Flexible versus dedicated automation - J.C. PEARCE \& R.D. McDOWALL

非 NC(F)- 8 Design of and first experiments with a bioluminescence detector for HPLC - H.M. RUIJTEN, B.E. TIMMERMAN \& H. DE BREE

非 NC(F)-9 A system approach to immunoassay using enhanced luminescence - M.R. SUMMERS, K. MASHITER, J.C. EDWARDS, J.K. MARTIN, G.P. DAVIDSON \& J. HOLIAN

Groupings of 'Notes' on particular themes:

Column switching (cf. 非-1): 非C (E)-2\&-3; also p. 308 Solid-phase sample processing: 非C (E) -8 to -11 ; also p. 308 NMR approaches: 非C $(F)-2$ to -6 


\section{List of Authors}

\section{Primary author}

M.F. Barkworth - p. 129 iphar Inst, HöhenkirchenSiegertsbrunn, W. Germany

T.J.A. B1ake - pp. 353-359

Smith Kline \& French Research, Welwyn, Herts.

U.A.Th. Brinkman - pp. 321-338 Free Univ., Amsterdam

A.P. Bruins - pp. 339-351

Rijksuniversiteit, Groningen

A. Bye - pp. 97-105

Upjohn Research Labs., Crawley

J. Caldwe11 - pp. 257-261 ( $\&$ see Hutt)

St. Mary's Hosp. Med. Sch., London W2

F. Carey - pp. 43-50

ICI Pharm1s., Alderley Park

S.H. Curry - pp. 213-214

Coll. of Pharmacy, Univ. of Florida, Gainesville, FL

B.E. Davies - pp. 179-183

Beecham Pharmls. Medicinal Res. Cent., Harlow, Essex

H. de Bree ( $\&$ see Ruijten) - pp.

(i) 209-212; (ii) 251-255;

(iii) 273-276; (iv) 301-303

Duphar BV, Weesp, The Netherlands

P.H. Degen - pp. (i) 107-114

(ii) 193-200

Ciba-Geigy, Basle

M.V. Doig - pp. 53-55

We11come Res. Labs., Beckenham

J.G. Dorsey - pp. (i) 235-244;

(ii) 305-306

Univ. of Florida, Gainesville, FL

\section{Co-authors, with relevant name} to be consulted in left column

W. Adams - Bye

L.A. Allan - Vose (i)

B.A. Bailey - Hill (iii)

I.G. Beattie - Blake

K. Belsner - Höller

H. Bippi - Frölich

M.B. Bottorff - Wainer

0.A.M. Brockhoff - de Bree (ii)

R.D. Brownsill - Vose (i), (ii)

\& (iii)

F. Bucheli - Wyss
R.A. Clare - Doig

J.F. Darbyshire - Caldwe11

G.P. Davidson - Caldwell

L. Dehelean - Hill (iii)

B.J. de Jong - de Bree (iv)

G.J. de Jong - Brinkman

A. DeLacroix - Lecaillon

R.A. de Zeeuw - Feitsma

D. Donnell - Woodward

B.F.H. Drenth - Feitsma

J.P. Dubois - Lecaillon

C.J. Dyde - Barkworth
J.C. Edwards - Summers

C. E1combe - Nicholson (1)

L. Embrechts - Woestenborghs (ii) 


\section{Primary author}

J. Fauler ( $\&$ see Frölich) -

pp. 35-39

Medical Sch., Hannover, W. Germany

K.G. Feitsma - pp. 265-268

Rijksuniversiteit, Groningen

J.C. Frölich - pp. 15-21

Medical Sch., Hannover, W. Germany

H.M. Hill - pp. (i) 269; (ii) 277-278;

(iii) 299-300

Bio-Research Labs., Senneville, Quebec

M. Höller - pp. 23-27

Janssen Res. Foundation,

Neuss, W. Germany

A.J. Hutt ( $\&$ see Caldwe11) -

pp. $115-125$

Brighton Polytechnic, Brighton

W.iv. Jenner - pp. 77-86

Glaxo Group Res., Ware, Herts.

J.B. Lecaillon - pp. 225-233

Ciba-Geigy Pharm. Res. Centre, Rueil-Malmaison, France

R.D. McDowa11 - pp. (i) 201-206:

(ii) 393-396

Smith Kline \& French Research, Welwyn, Herts.

J.C. McE1nay - pp. 87-95

Queen's Univ., Belfast

P.S.B. Minty - pp̃. 159-161

Charing Cross \& Westminster Mied.

Sch., London W6

G.P. Mould - pp. 185-191

St. Luke's Hosp., Guildford

J.K. Nicholson - pp. (i) 375-381;

(ii) 383-388

Birkbeck Co11., London WC1

K.D. Rainsford - pp. 67-74

Strangeways Res. Lab., Cambridge

A. Rakhit - pp. 135-142

Ciba-Geigy Pharm1s. Divn,, Summit, NJ
Co-authors, with relevant name to be consulted in left column

K.A. Fernandes - McDowal1 (i)

J. Firth - Vose (i)

R.A. Forder -Carey

U. Förstermann - Frölich

A. Gescher - Threadgill

C. Gooijer - Brinkman

A. Gray - Vose (ii) \& (iii)

A.J.E. Green - Mould

C.P. Groen - de Bree (iv)

A.J. Hawkins - Vose (i)

D. Haworth - Carey

J. Heykants - Woestenborghs

(i) \& (ii)

J. Holian - Summers

J.J.M. Holthuis - Vendrig

P.R. Hurst - Whelpton

J.A. Je11y - McDowa11 (i)

V. Kaever - Fauler

D. Kaiser - Bye

D. J. Kirkham - Jenner

H-R. Kwon - Curry

R.L. Lalonde - Wainer

N. Lammers - de Bree (iv)

W.J. Leavens - McDowal1 (i)

R.M. Lee - McDowa11 (i)

D. Lessard - Hill (ii)

L. Letarte - Hill (ii)

P.A. Lewis - Woodward

S. Lewis - J.D. Robinson

I. Luhmann - Höller

C.M. Macdonald - Nicholson

(ii)

J. Maddock - Woodward

J.K. Martin - Summers

K-H. Marx - Frölich \& Fauler

K. Mashiter - Sumners

D.K.F. Meijer - Feitsma

A. Mekking - Vendrig

G.S. Murkitt - McDowall (i)

B. Osikowska-Evers - Höller

R.P.B. Passas - Stevenson

J.C. Pearce - McDowa11 (i) \& (ii)

R. Pickford - Wilson (iii) 


\section{Primary author}

K-D. Rämsch - pp. 163-164

Bayer Inst. f. Klin. Pharmacologie, Wupperta1, W. Germany

C. Robinson - pp. 3-13

Univ. of Southampton

J.D. Robinson - pp. 143-148

Hoechst UK, Walton Milton Keynes

H.M. Ruijten [ $\&$ see de Bree (iv)]

- pp. 397-399

Duphar, Weesp, The Netherlands

D. Stevenson - pp. 279-281

Univ. of Surrey, Guildford

M.R. Summers - pp. 401-402

Amersham Internat1., Amersham, Bucks.

M.D. Threadgi11 - pp. 389-392

Univ. of Aston, Birmingham

D.E.M.M. Vendrig - pp. 283-288

Rijksuniversiteit, Utrecht

C.W. Vose - pp. (i) 29-35;

(ii) 363-365; (iii) 367-369

Hoechst UK, Walton Milton Keynes*

I.W. Wainer - pp. 169-177

St. Jude Children's Res. Hosp.,

Memphis, TN

R. Whelpton - pp. 289-294

London Hosp. Med. Col1., London E1

I.D. Wilson - pp. (i) 295-298;

(ii) $313-320$ (iii) $371-374$; (iv) 383-388.

ICI Pharmls., Alderley Park

R. Woestenborghs - pp. (i) 149-155;

(ii) 215-216

Janssen Res. Foundn., Beerse, Belgium

A.J. Woodward - pp. 245-250

Simbec Res., Merthyr Tydfil, Wales

P.M. Woollard - pp. 57-58

Wellcome Res. Labs., Beckenham ${ }^{\dagger}$

R. Wyss - pp. 271-272

Hoffmann-La Roche, Basle
Co-authors, with relevant name to be consulted in left column

\author{
K.D. Rehm - Barkworth \\ B. Rosenkranz - Frölich \\ R.J. Ruane - Wilson (i) \\ S.M. Sanins - Nicholson (i) \\ D. Scherling - Rämsch \\ K. Selinger - Hill (i) \\ K. Sierat - de Bree (i) \\ I.K. Smith - Wilson (iii) \\ C. Souppart - Lecaillon
}

J.A. Steiner - Vose (i)

T. Teeuwsen - Vendrig

J.A. Timbrell - Nicholson (i)

B.E. Timmerman - Ruijten

P. Timmerman - Woestenborghs

G.P. Tomkinson - Wilson (i)

J. Troke - Nicholson (ii)

F.A. Tucker - Minty

M.P. van Berkel - de Bree

(i)

D.J.K. van der Stel - de

Bree (ii)

A. van Peer - Woestenborghs

(i)

K.E. Wade - Nicholson (ii)

C.M. Walls - Vose (iii)

C. Weber - Höller

S.M. Winter - Caldwel1

Former 'affiliations': ${ }^{*}$ G.D. Searle, High Wycombe; ${ }^{\dagger}$ Inst. of Dermatology 